\title{
Efforts to Develop Religious and Moral Value Ability (Identify Know Salah Times) Using a Combination of Rhyming Method and Make A Match Model
}

\author{
Aslamiah $^{1}$, Ishak $\mathrm{Sin}^{2}$, Diani Ayu Pratiwi ${ }^{1 *}$, Dina Miliyawati ${ }^{1}$ \\ IEarly Childhood Teacher Education Program, Universitas Lambung Mangkurat, Banjarmasin, Indonesia. \\ ${ }^{2}$ College of Art and Sciences, Universiti Utara Malaysia, Sintok, Kedah Darul Aman, Malaysia
}

\begin{tabular}{|c|c|}
\hline ARTICLE INFO & A B STRACT \\
\hline \multirow[t]{2}{*}{$\begin{array}{l}\text { Received: 02-I I-20I8 } \\
\text { Revised: 20-I2-20I8 } \\
\text { Accepted: 27-I2-20I8 } \\
\text { Keywords: } \\
\text { rhyming, make a match, } \\
\text { religious and moral value } \\
\text { ability development } \\
\text { (identify Salah times) }\end{array}$} & $\begin{array}{l}\text { This is a classroom action research (CAR), which aims to identify the } \\
\text { improvement of learning development outcome in developing the religious and } \\
\text { moral value ability in recognizing Salah times by using a combination of rhyming } \\
\text { method and make a match model in group A TK Nusa Indah Alalak Subdistrict, } \\
\text { Barito Kuala Regency, involving } 16 \text { children consisting of } 9 \text { boys and } 7 \text { girls in the } \\
\text { second semester of 20I6/20I7 school year. This research was conducted in two } \\
\text { cycles, each cycle consists of two learning meetings. The research data source was } \\
\text { obtained from the learning process using the combination of rhyming method and } \\
\text { make a match model with the observation on teacher and children activities, the } \\
\text { data in the form of evaluation was analyzed using percentage technique taken from } \\
\text { the results of children worksheet (LKA). The learning implementation instruments } \\
\text { as a support for this research were in the form of curriculum, syllabus, and RKH } \\
\text { (daily activity plan). The data source in this research was group A children of TK } \\
\text { NUSA INDAH, Alalak Subdistrict, Barito Kuala Regency. This research shows } \\
\text { the development of religious and moral value ability (identifying Salah times) } \\
\text { classically had obtained a score of } \geq \star \star \star 93.75 \% \text { and it was declared as } \\
\text { successful in developing. }\end{array}$ \\
\hline & $\begin{array}{l}\text { (c) } 2018 \text { The Authors. Journal of K6, Education, and Management (j-K6EM). ISSN: } 2580-2135 . \\
\text { Published by Graduated Program of Educational Management, Universitas Lambung } \\
\text { Mangkurat, Banjarmasin, Indonesia. This is an open access article under the open journal } \\
\text { systems. }\end{array}$ \\
\hline
\end{tabular}

*Author correspondence: Diani Ayu Pratiwi; E-mail: dianiayupratiwi@gmail.com 


\section{Introduction}

In this modern time, the religious and moral values specifically have begun to wear off, and this is influenced by several factors such as poor fostering and habituation of moral and religious value since an early age. This should be instilled, applied, and accustomed since early age to provide foundation for the individual in facing the future life changes where religious and moral values have begun to be forgotten. This is where parents and educational institution are expected to play an active role in dealing with religious and moral value development aspect. According to Yusuf (2012), development is a change experienced by individuals towards the level of maturity that is influenced by environmental factors. Therefore, parents should be able to give directions to children because parents are the first and foremost educator in children's life.

Suyadi (20I4) states that early childhood education essentially is an education held with the aim to facilitate the growth and development of children as a whole or emphasize all aspects of the children personality development, in order to create a good and moral generation. Based on TK (Kindergarten) Curriculum data (2010), to develop all the children's diverse potentials, an active, creative, effective, and enjoyable learning is needed. One of them is on the aspect of behavior formation development, namely religious and moral value aspects.

In the Regulation of the Minister of National Education Number 58 of 2009 on Early Childhood Education standard, it states that there are 5 aspects of early childhood development that can be developed including: I) Religious and moral values, 2) Cognitive, 3) Language, 4) Emotional social, and 5) Motoric physics. Based on TK curriculum data (2010) on Religious and Moral Value aspects in recognizing Salah times, group A children or children aged 4-5 years should have been able to recognize the Salah times with indicators as follows: I) Able to mention the Salah times with the clock concept, 2) Able to mention the Salah times with the concept of noon, afternoon, or evening, 3) Able to mention the order of Salah times. But the fact is the group A children of TK Nusa Indah Alalak Subdistrict, Barito Kuala Regency in the second semester of 2016/2017 school year did not meet the indicators of Religion and Moral Values and this is the problem for group A children of TK Nusa Indah Alalak Subdistrict Barito Kuala Regency.

This is caused by the abstract, boring, and less attractive learning process for the children. In addition, the learning materials were not applied in the long term, so that it is only applied temporarily or the learning material is quickly forgotten by children due to lack of habituation so that they become less active in the learning process. Based on the fact at TK Nusa Indah Alalak Subdistrict, Barito Kuala Regency on 16 children group A of 9 boys and 7 girls in the second semester of 2016/20I7 school year, most children still do not know the Salah times. This has an impact on the low children learning outcomes in identifying the Salah only $6.25 \%$ of 16 children in group A, and it means that only I child has developed very well $(\star \star \star \star)$, and $12,5 \%$ of children developed according to expectation $(\star \star \star)$ or only 2 children, $18.75 \%$ began to develop ( $\star \star$ ) or only 3 children began to develop, and $62.25 \%$ of children who did not develop ( $\star$ ) or 10 out of 16 children has not developed yet.

From the description, the researchers took alternative problem solving by conducting 2 cycles of research with 2 meetings in each cycle in developing the religious and moral value ability to identify the Salah times in group A children of TK Nusa Indah, through a combination of rhyming method and make a match model. Rhyming method is a learning method by using tones with the beauty of words, intertwined according to meaning and rhythm to express certain circumstances or ideas and usually consists of several lines that end with the same sound (Supriadi, 2003). This activity will be accustomed to each meeting so that it allowed the children to recite it frequently making them to always remember the contents of the rhyme spoken. This activity will allow the children to get used to saying and remembering, in other words the knowledge gained will last long or not be quickly forgotten by the habituation process. Habituation is an effective strategy to shape certain behaviors in children, including the behavior of religious and moral values because by habituation a relatively fixed embedded behavior is formed. The rhyming method is used as a habituation activity at each meeting. This was conducted to implement learning materials over a 
long period of time so that the learning was not quickly forgotten by children, and the children would be actively participate in the learning process. It means that the teachers will always invite the children to repeat and follow them in rhyming, this can lead to the children involvement in learning activities.

The rhyming method is a method used to imitate the pronunciation of something in order to improve the children focus on learning. In line with this, other studies also suggest the importance of childcentered learning approach in religious education so that the learning process can follow the phase of growth and development of children and their characteristics (Ali, 20I5).

The rhyming or singing method is a method that can be used in developing religious learning. The rhyming method shows activities to express the beauty of intonation and rhythm. As stated by Ali (2015), the singing method has a number of benefits for children, which will make it easier for children to absorb the material delivered, motivate the students to learn, make teaching and learning fun, make difficult learning easier, build the relationship between teachers and students or bring the relationships between students closer.

In addition to strengthen the children's memories of learning that is still abstract, the use of make a match model is appropriate to be implemented in optimizing the learning. The make a match model is a learning model which requires children to look for the pairs of cards, which are specific material answers/questions in learning. One of the advantages of this technique is that the children can look for the pair while learning about a concept/topic in a fun atmosphere (Shoimin, 20I4). In this case, the cards presented were in the form of pictures that must be paired based on the correct answer to the picture, it is used as a review session of the children understanding.

The purpose of this research is to find out: (I) teacher activities in improving the religious and moral values of children by using a combination of rhyming method and make a match model in learning to identify the Salah times in group A children of TK Nusa Indah, Alalak Subdistrict, Barito Kuala Regency; (2) children activities in improving the religious and moral values while participating in learning to develop the religious and moral value ability in identifying Salah times using a combination of rhyming method and make a match model in group A TK Nusa Indah Alalak Subdistrict, Barito Kuala Regency; (3) improvement in learning outcomes in developing the religious and moral value ability in identifying Salah times by using a combination of rhyming method and make a match model in group A children of TK Nusa Indah Alalak Subdistrict, Barito Kuala Regency.

\section{Methodology}

The research type used is classroom action research (CAR) with the aim to improve learning in the classroom. This improvement effort was carried out by finding the answers to the problems raised in daily tasks in the classroom, so that the classroom action research provided practical and applicative meaning to be implemented in learning to improve the learning quality and outcomes (Suriansyah, 2013).

In this research, the researchers used action research method namely Kemmis and Mc Tagart method. This method consists of four components, i.e. planning, action, observation, and reflection as one cycle. This class action research was conducted at TK Nusa Indah in Alalak Subdistrict, Barito Kuala Regency. This research was conducted in group A (4-5 years old), this research is a classroom action research where the researchers also act as the implementing teacher. The research was conducted on class A group with a total of 16 children consisting of 9 boys and 7 girls.

The research factors observed here were teachers, children and increase in the results of learning development in developing the religious and moral value ability in recognizing Salah times. The success indicators in this research were: the teacher activities were successful if at least reached good or very good category with a minimum score of $2 \mathrm{I}$, the children activities were successful if reached active or very active category with a minimum percentage of $8 \mathrm{I}$ and if classically reached at least $81 \%$. The religious and moral value ability in identifying Salah times is successful if individually the children succeeds to obtained at least 3 stars $(\star \star \star)$, classically the children success if at least obtained $81 \%$ by 3 stars $(\star \star \star)$ ) with developed according to expectation category.

There are steps to implement the learning process using a combination of rhyming method and make a match model that have been adapted to early childhood, as follows: (I) Teacher first recites the verse; (2) Teacher repeats the verse repeatedly until the child can pronounce it independently or memorize it; (3) Teacher prepares several cards containing several concepts or topics suitable for 
the review session, one for the question card and the other is answer card; (4) Every student gets one card; (5) Each student thinks of answers/questions from the card held; (6) Every student looks for a partner who has a card that matches his/her card; (7) Every student who can match the card before the given time get a point; (8) After one round the card is re-shuffled so that each student gets a different card, and so on; (9) After the students match the card, each pair is given the opportunity to convey the results of the card match and the teacher gives the opportunity for the children to come forward to recite the verse; (I0) Teacher provides guidance and encouragement when the children learns to rhyme; (I I) Conclusion/closing.

The stages of implementing the combination of rhyming method and make a match model were carried out in two cycles, each cycle consisted of two learning meetings. The data source of this research was obtained from the learning process using the combination of rhyming method and make a match model with the observation of teacher and children activities, the data in the form of evaluations were analyzed using percentage technique taken from the results of the children worksheet (LKA). The learning implementation instrument as a support for this research was in the form of curriculum, syllabus, and RKH (daily activity plan). The data source in this research was the group A children of TK Nusa Indah, Alalak Subdistrict, Barito Kuala Regency.

The criteria for the implementation success can be represented as follows: ^ Has not developed yet (BB) in which Children are not able to carry out the activities requested by the teacher; $\star \star$ Begins to develop $(\mathrm{MB})$ in which Children are able to carry out activities requested by the teacher but with assistance; $\star \star \star$ Develop as expected (BSH) in which Children are able to carry out activities requested by the teacher without assistance; $\star \star \star \star$ Very good development (BSB) in which Children are able to carry out activities beyond what the teacher asks. The results of children ability development category are said to be successful if in the religious and moral values in identifying the Salah times, especially using a combination of rhyming method and make a match model obtain a minimum of $81 \%$ or at least

\section{Results and Discussions}

The result of cycle I of meeting I for children activities show that the class average in children learning activities was in "Fairly Active" category with a score of 54.29. Observation result of cycle I of meeting I was in less active category by 6 children with percentage of $37.5 \%$, I0 fairly active children by $62.5 \%$, 0 active child and there was still no child who obtained very active category.

Based on the results of observation showed from the table above, the comparison of children who get the category of less active, quite active, active, and very active can be seen. There were 6 children in less active category, I0 children in fairly active category, 0 child in active category, and 0 child $s$ in very active category. So classically, the results of observation on children activities in cycle I of meeting I that obtained active and very active description was 0 .

The observation results of religious and moral values development in the cycle I of meeting I revealed that there were 3 children who had not developed yet (BB). Children who started developed (MB) as many as $\mathrm{IO}$ children. And those who were according to expectation (BSH) were 3 children. For developed very well (BSB) was 0 child. The results of the development of religious and moral value ability of children of cycle I of meeting I was $\geq \star \star \star$ Successfully developed was 3 with percentage of $18.75 \%$, and $<\star \star \star$ had not developed yet successfully was I3 children by $81.25 \%$.

Therefore, the success of children classically was I8.75\%. The teacher activities in the learning activities carried out obtained a score of I5. This showed the teacher activities in learning was classified as "Good". The teacher activities at meeting I was said to have not been successful, because the teacher activities were said to be successful if it reached a minimum score of $2 \mathrm{I}$ with a very good category. In general, the learning process carried out by the teacher had taken place quite effectively. This was due to the score of 2 obtained from step 2.4 and 6 .

The observation results of teacher activities in cycle I of the meeting 2 showed that the teacher activities in learning obtained a score of I8 with "Good" category. This was seen from several aspects of the observation of teacher activities that were still not implemented properly so that they only obtained 3 .

For the children learning activities in cycle I of meeting 2, they still received "Fairly Active" category with a score of 55.95 even though the score had increased. Observation results of children activities from several aspects were: (I) Children listened to the teacher delivered the material 
presented, there was no child in very active category, 7 children in active category, 9 children in active category, and 0 child in less active category. (2) When children answered the questions posed by the teacher, there was no child in very active category, 8 children in active category, 8 children in fairly active category, and 0 children in less active category.

(3) When children listened to the rhyme, there was no child in very active category, 7 children in active category, 9 children in fairly active category, and 0 child in less active category. (4) When children come forward to recite the rhyme there was no child in very active category, 2 children in active category, 12 children in fairly active category, and 2 children in the less active category.

(5) When children paid attention to teacher guidance there was no child in very active category, 4 children inactive category, 12 children in fairly active category, and 0 child in the less active category. (6) When children listen to the conclusions there was no child in very active category, 3 children in the active category, II children in fairly active category, and 2 children in less active category. There were 2 children in less active category, IO children in fairly active category, 4 children in active category, and 0 child in very active category. So in classical terms the observation results of children activities in cycle I of meeting 2 received were 4 children in active category and 0 child in very active category.

Based on the results of the development of religious and moral value ability in cycle I of meeting 2 , the percentage of success obtained was $43.75 \%$ with the details that can be seen as follows: child who has not developed yet $(\mathrm{BB}) \star$ was 0 and percentage $0 \%$, children who started developing $(\mathrm{MB}) \star \star$ were 9 children by $56.25 \%$, and developing according to expectation (BSH) $\star \star \star$ were 7 children by $43.75 \%$ and developing very well (BSB) $\star \star \star \star$ was 0 child.

Observation of teacher activities in cycle II of meeting I was the teacher activities in learning obtained a score of 2I with Very Good Category. This is seen from several aspects of the observation of teacher activities that are getting better by implementing aspects that are evaluated on the observation sheet of teacher activities.

The observation results of children activities in cycle II of meeting I in general can be said to run very smoothly. This can be proven based on the score that had reached the average in the children learning activities in Active category with a score of
65.88. By processing the comparison of children who obtained the category of less active, fairly active, active, and very active, there was 0 child in less active category, 3 children in fairly active category, 9 children in active category, and 4 children in very active category. So classically, the observation results of children activities in cycle II of meeting I were $\mathrm{I} 3$ children in active and very active category.

From the observation results on the development of the religious and moral value ability of children in cycle II of meeting I, it could be seen that there was 0 child who has not developed yet (BB). Children who started developing (MB) as many as 8 children with a percentage of $50 \%$, and developing according to expectation (BSH) as many as 8 children with a percentage of $50 \%$, and for developing very well (BSB) was 0 child.

Based on the observation of teacher activities carried out in group A in cycle II of meeting 2 on learning to identify the Salah time, the teacher activities in learning obtained a score of 23 with "Very Good" category, there was only I aspect that obtained a score of 3 , which was in step 6 . The score was success if it has been able to reach above the score of $2 \mathrm{I}$.

Observation of children activities in cycle II of meeting 2 in general can be said to run very smoothly. Based on the score acquisition, it could be seen that the average in the children learning activities with the category Very Active had a score of 89.3I. There was 0 child in less active who participated in learning activities, I child in quite active category, 3 children in active category, and I 2 children in very active category. The children activities that reached a score of $89.3 \mathrm{I}$ were said to be succeeded if the average class score of children activities reached a minimum of $8 \mathrm{I}$ while the result obtained had exceeded the desired score.

Observation results in developing the religious and moral value ability of children in cycle II meeting 2 were: the children who has not developed yet (BB) $\star$ was 0 . Child who started developing (MB) as many as I child with a percentage of $6.25 \%$, and developing according to expectation (BSH) $\star \star \star \star$ as many as 8 children by $50 \%$, and for developing very well (BSB) $\star \star \star \star$ as many as 7 children by $43.75 \%$. Therefore, the acquisition in the cycle II of meeting 2 was stated to have been able to reach the success indicator with a score of $\geq \star \star \star$ $93.75 \%$ and was declared as developed successfully.

The following is trend graph on the results of teacher activities, children activities, and 


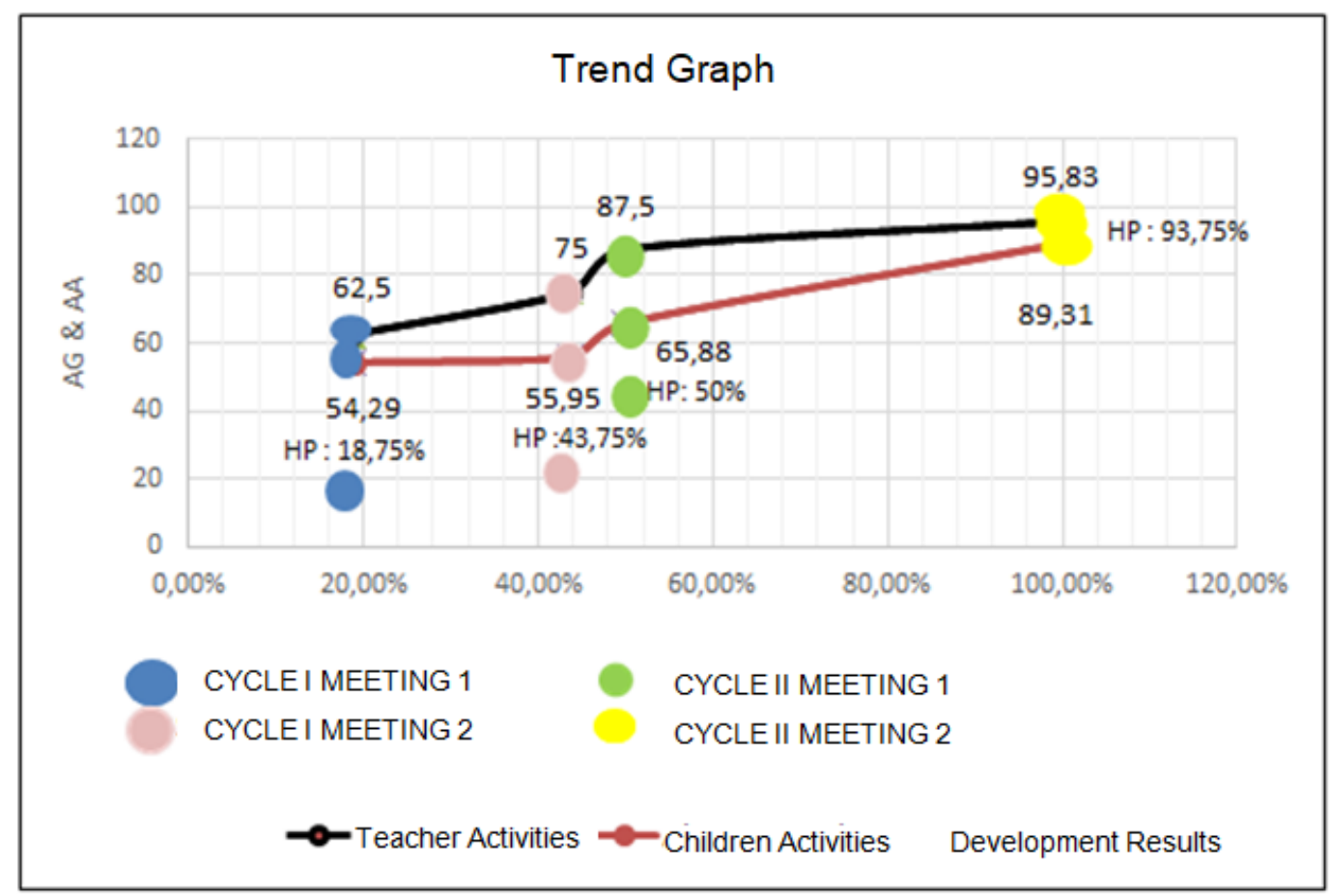

From the graph above, it shows the relationship of function between teacher activities, children activities and the results of development. If the teacher activities improve in carrying out learning through a combination of rhyming method and make a match model in the aspects of developing moral religious values in recognizing the Salah times (prayer five times), then the results of children development are also growing. Likewise, if children become more active to participate in learning activities through a combination of rhyming method and make a match model, the results of children development are also growing. It is very clear that the application of a combination of rhyming method and make a match model can develop children activities.

Child activities in learning used a combination of rhyming method and make a match model from cycle I to cycle II increased. In cycle I of meeting I, the score was 180 or $54.29 \%$ with fairly active category while the cycle I of meeting 2 increased by obtaining a score of 215 or $55.95 \%$ with fairly active category. Then in cycle II of meeting I the score obtained was 253 or $65.88 \%$ with active category. In cycle II of meeting 2, it increased again by obtaining a score of 343 or $89.31 \%$ with very active category. The increase of children activities in learning occurs because through the habituation of rhyming method which is always carried at the beginning of core activities, the knowledge acquired by children in learning activities is easier to absorb and remember. This is related to the opinion of Al-
Ghazali in Yusuf (2012), which states that in providing education about the religious and moral values, it should be emphasis more on habituating the activities which may become a habit for children in their daily lives. Learning through habituation is the process of forming new habits or improving the existing habits to make the students obtain new attitudes and habits that are more appropriate and positive in the sense of harmony with the needs of space and time (Shah, 2003), or the process of change that results from learning activities. This is in line with Hamalik (2013) that the evidence that someone has learned is the changes in behavior occurred in an individual, for example from not know to knowing, and from not understand to understanding. This is also related to the opinion of Rusman (2012) who states that the learning process will occur if the children interact actively with their learning environment.

The early age is the right time to lay the foundation for the growth and development of children. Because the results of child development are the results obtained by children after the learning activities. According to Sujiono (20I2), conducive situation and condition are needed when providing appropriate simulation and educational efforts to the needs and interests of children, so that the growth and development can be achieved optimally. In addition, Busthomi (2012) argues that activities for early childhood are more intended to develop the attitude, knowledge, skill and creativity needed 
by children to live in the community and preparation to enter school.

It can be seen that from cycle I to cycle II that there was an increase, where in cycle I of meeting I there were 3 children or $18.75 \%$ who succeeded in developing, while I3 children or $81.25 \%$ had not succeeded in developing. However, in cycle I of meeting 2 , there was an increase, there were 5 children or $31.25 \%$ who had succeeded in developing while II children had not succeeded in developing or $68.75 \%$. Whereas in cycle II of meeting I there were 8 children or $50 \%$ who succeeded in developing while there were 8 children who had not succeeded in developing or $50 \%$, whereas in cycle II of meeting 2 there were 15 children or $93.75 \%$ who had succeeded in developing while those who had not succeeded in developing was I child or $6.25 \%$. The use of learning model appropriate to the children characteristics can improve the learning outcomes (Masitoh, 2012)

In addition, success in children activities lies on teachers' role who demands the children to be actively involved in answering questions from the teacher verbally, so that it will affect children, and allowing children to think, answer, and ask by themselves will increase children's confidence. This is in line with the opinion of Uno and Nurdin (20I5) that active learning strategy is where students are expected to be actively involved in learning activities to think, interact, try, find new concepts, or produce a work. Instead, children is not expected to passively accept everything like an empty glass waiting to be filled.

Based on classroom action research cycle I and cycle II, it can be seen that there is an increase in each meeting both from teacher activities, children activities, and child development outcomes. This research was supported by several research carried out by people specifically those related to the combination of rhyming method and make a match model that can help develop child development aspects, for example Rachma Dian (2007), about increasing skills in writing descriptive paragraphs through suggestion-imagination method with song media on class XA students of SMAN 2 Blora. In addition there were also Olo Tahe Sinaga 920I4) research from Language and Art Faculty of University of Semarang, which talked about the use of song and rhyming media in an effort to improve Indonesian speaking skills of beginner-level BIPA students at Multimedia University Nusantara (a learning model for beginner-level BIPA students at Multimedia Nusantara University, Tangerang),
Budianti Sulistianingtyas (2015) who discussed learning English using song media at local culturebased school in SMK 8 Surakarta, Muhammadiyah University of Surakarta.

Based on the overall final test research, the researchers ended the class research action in group A of TK Nusa Indah, Alalak Subdistrict, Barito Kuala Regency with the conclusion that when a combination of rhyming method and make a match model were used they could develop children's religious and moral values in identifying Salah times in group A children of TK Nusa Indah Alalak Subdistrict, Barito Kuala Regency. This rhyming method can help children to be active in learning activities since this method requires children to always follow what the teacher instructs with fun learning.

Isjoni (Shoimin, 20I4) says that the make a match model is developed by Loma Curran. The main feature of this model is that students are asked to look for pairs of cards consisting answers or questions of certain material in learning. One of the advantages of this technique is that students look for partners while learning about a concept or topic in a fun atmosphere. This technique can be used in all subjects and for all age levels.

The characteristics of the make a match learning model have a close relationship with the student characteristics who like to play. The implementation of make a match model must be supported by the student activities to find pairs of cards that match the answers or questions on the card. Students who study with make a match model are active in learning so they can have meaningful learning experiences (Shoimin, 20I4).

This learning model is able to develop the religious and moral value ability (getting to know Salah time) through the steps of combination of rhyming method and make a match model that has been adapted to early childhood. The learning step begins with the teacher recites the verse first and through this activity the children are invited to sing so as to provide a new nuance in the learning process that can foster motivation in children to start learning. This is in line with Ali's (2015) statement in his research, which concluded that through the rhyming method presented with song elements can stimulate children's motivation in learning. The activity is carried out repeatedly until the children can say independently or memorized it. In this research, the singing activities are filled with advice verse, which can gradually develop children's morale towards a positive direction. The research 
by Seriati \& Hayati (2012) also found that learning by singing/rhyming also had an impact on children's morals such as on the children social skills.

Teacher prepares several cards containing several concepts or topics suitable for the review session, one part is question card and the other is answer card; (4) Every student gets one card, each student thinks of answers/questions from the card held; (6) Every student looks for a partner who has a card that matches their card; (7) Every student who can match their card before the deadline obtains a point; (8) After one round the card is shuffled again so that each student gets a different card than before, and so on; Therefore the picture serves to strengthen children visual that are able to identify Salah times. This is in line with Soraya's (2013) research result that the use of picture becomes a way in teaching tolerance to children.

Then the learning is continued after the students match the card, each pair is given the opportunity to deliver the card match results and the teacher provides an opportunity for the child to come forward to recite the verse, then the teacher provides guidance and encouragement when the child learns to rhyme, learning ends by drawing conclusions shared by the teacher and children.

\section{Conclussion and Recomendations}

Based on the results of research and discussion in this research, namely developing the ability of religious and moral values in recognizing the Salah times using a combination of rhyming method and make a match model in group A children of TK Nusa Indah Alalak Subdistrict, Barito Kuala Regency can be increased, this can be seen below:

I. Teacher activities develop the ability of religious and moral values in recognizing the Salah times using a combination of rhyming method and make a match model in group A children of TK Nusa Indah Alalak Subdistrict, Barito Kuala Regency according to the steps adjusted with early childhood had been implemented with very good category.

2. Children activities in developing the religious and moral value ability in identifying the Salah times using a combination of rhyming method and make a match model on group A children of TK Nusa Indah, Alalak Subdistrict, Barito Kuala Regency had been implemented well and the achievement of children activities are included in very active category.

3. The children development results in developing the religious and moral value ability in identifying the Salah times using a combination of rhyming method and make a match model in group A children of TK Nusa Indah, Alalak Subdistrict, Barito Kuala Regency could be carried out well with very well developed category or four stars $(\star \star \star \star)$.

The results of this research are expected to provide benefits both to the teachers and principals as well as to further researchers, among others:

I. For school principals

This research can be used as an input in carrying out guidance to teachers so that it can improve the quality of learning and education.

2. For teachers

This research can be used as an input and alternative method or model in developing the aspects of early childhood development.

3. For the future researchers

This research can be used as well as possible so that the findings obtained can be applied and developed for educational purposes in an effort to improve the learning quality in kindergarten.

\section{Acknowledgment}

We would like to express our gratitude to those who have supported this research: In writing this journal article, the writers were greatly assisted by many parties, especially the principal of TK Nusa Indah Alalak Subdistrict, Barito Kuala Regency and the entire board of teachers who had provided a chance to conduct research as well assistance in obtaining data so that this journal article can be completed properly.

\section{References}

Ali, M.M. (2015). Pembelajaran Pendidikan Agama Islam Bagi Anak Usia Dini. Jurnal Edukasi. I90$2 \mathrm{I} 5$.

Busthomi, Y. (2012). Panduan Lengkap PAUD Melejitkan Potensi Anak. Jakarta: Citra Publishing.

Dian, Rachma. (2007). Peningkatan Keterampilan Menulis Paragraf Deskripsi Melalui Metode SugestiImajinasi Media Lagu Siswa Kelas X A SMA Negeri 2 Blora. Surakarta: Universitas Muhammadiyah Surakarta. 
Hamalik, Omear. (2013). Proses proses belajar mengajar. Jakarta: Bumi Aksara.

Masitoh. (20I2). Strategi pembelajaran di TK. Jakarta: Kencana Prenadamedia Group.

Rusman. (2012). Manajemen Kurikulum. Jakarta: PT Raja Grafindo Persada

Seriati, N.N., \& Hayati, N. (20I2). Permainan Tradisional Jawa Gerak dan Lagu Untuk Menstimulasi Keterampilan Sosial Anak Usia Dini. Jurnal Tugas Akhir Mahasiswa Universitas Negeri Yogyakarta. I-I5.

Shoimin, A. (20I4). 68 Model Pembelajaran Inovatif dalam Kurikulum 2013. Yogyakarta: Ar-Ruzz Media.

Sinaga, olo tahe. (2014). Penggunaan Media Lagu Dan Puisi Dalam Upaya Meningkatkan Kererampilan Berbicara Bahasa Indonesia Pada Siswa BIPA Tingkat Pemula Di Universitas Multimedia Nusantara (Sebuah Model Pembelajaran Pada Siswa BIPA Tingkat Pemula Di Universitas Multimedia Nusantara, Tangerang). http://www.ialf.edu/asile/OloTaheSinagaPenggunaanMediaLagudan http://www.ialf.edu/asile/OloTaheSinagaPenggunaanMediaLagudan Puisi.pdf. diakses pada tanggal 2I Februari 2017.

Soraya, S. (2013). Studi Eksperimen Penggunaan Media Diversity Doll dan Media Gambar sebagai Penanaman Sikap Toleransi Anak Usia 4-6 Tahun Di Raudhotul Athfal 02 Mangunsari Semarang. Indonesian Journal of Early Childhood Education Studies. $37-42$. http://journal.unnes.ac.id/sju/index.php/ijeces

Sujiono, Yuliani, Nurani. (2012). Konsep Dasar Pendidikan AUD. Jakarta: Universitas Terbuka

Sulistianingtyas, Budianti. (2015). Pembelajaran Bahasa Inggris Menggunakan Media Lagu Pada Sekolah Berbasis Budaya Lokal Di SMKN 8 Surakarta. Universitas Muhammadiyah Surakarta. http://eprints.ums.ac.id/40388/I/Naskah\%20Pu blikasi.pdf

http://eprints.ums.ac.id/40388/I/Naskah\%20Pu blikasi.pdf diakses pada tanggal 2I Februari 2017.

Suriansyah, Ahmad. (2013). Panduan Penulisan Karya Ilmiah Program Studi Pendidikan Guru Sekolah Dasar Universitas Lambung Mangkurat. Banjarmasin: UNLAM.

Suyadi. (2014). Teori Pembelajaran Anak Usia Dini dalam Kajian Neurosains. Bandung: Remaja Rosda Karya.

Syah, Muhibbin. (2003). Psikologi Belajar. Jakarta: PT Rajagrafindo Persada.

Uno, Hamzah B, Nurdin Mohammad. (2015). Belajar Dengan Pendekatan PAILKEM: Pembelajaran Aktif, Inovatif, Lingkungan, Kreatif, Efektif, Menarik. Jakarta: PT Bumi Aksara.

Yusuf, Syamsu, L.N. (2012). Psikologi Perkembangan Anak Dan Remaja. Bandung: PT Remaja Rosdakarya.
Yusuf, Syamsu. L.N., \& M. Sugandi, Nani. (20I4). Perkembangan Peserta Didik. Jakarta: PT Tajagrafindo Persada. 
ISSN 2580-2135 